\title{
Skrining Thalassemia Beta Minor pada Siswa SMA di Jatinangor
}

\author{
Putri Alyumnah, ${ }^{1}$ Mohammad Ghozali, ${ }^{2}$ Nadjwa Zamalek Dalimoenthe ${ }^{3}$ \\ ${ }^{1}$ Fakultas Kedokteran Universitas Padjadjaran, \\ ${ }^{2}$ Departemen Biokimia dan Biologi Molekular Fakultas Kedokteran Universitas Padjadjaran, \\ ${ }^{3}$ Departemen Patologi Klinik Fakultas Kedokteran Universitas Padjadjaran/Rumah Sakit Umum Pusat Hasan \\ Sadikin Bandung, Indonesia
}

\begin{abstract}
Abstrak
Jenis Thalassemia yang paling banyak ditemukan adalah Thalassemia beta. Tercatat $10 \%$ penduduk Indonesia merupakan pembawa gen Thalassemia beta. Thalassemia beta minor sulit dideteksi karena bersifat asimtomatik sehingga peranan skrining sebagai deteksi dini sangat diperlukan. Sampai dengan saatinidi Indonesiabelum dilakukan program skrining rutin Thalassemia. Tujuan penelitian ini untuk mengetahui frekuensi Thalassemia beta minor pada siswa- siswi SMA di Jatinangor. Metode penelitan deskriptif kuantitatif, dengan teknik pengambilan data cross sectional telah dilakukan sejak bulan September sampai dengan Oktober 2015. Subyek penelitian terdiri dari siswasiswi di 5 SMA kelas 10 dan 11 yang terregistrasi di Jatinangor. Hasil dari seluruh siswa-siswi kelas 10 dan 11 SMA di Jatinangor, hanya ada 292 yang hadir saat penyuluhan, dan hanya 130 orang di antaranya yang bersedia mengikuti penelitian. Pada penelitian ini ditemukan 12(9,3\%) orang sebagai thalassemia beta minor.Pembahasan pada penelitian ini ditemukan $12(9,3 \%)$ orang sebagai thalassemia beta minor. Pada penelitian lain di Banyumas didapatkan $8 \%{ }^{14}$
\end{abstract}

Kata kunci: Skrining, Thalassemia, Thalassemia Beta Minor.

\section{Suspected Beta Thalassemia Minor Screening in Jatinangor High School Students}

\begin{abstract}
The most common type of thalassemia found in Indonesia is beta thalassemia. There are around 10\% of Indonesia's population are beta thalassemia minor. Beta thalassemia minor is difficult to detect because it is asymptomatic. The role of screening as early detection is necessary, but until recently there is no routine screening thalassemia program conducted in Indonesia. The aim of the study is to determine the frequency of suspected beta thalassemia minor among the high school students in Jatinangor. Methods a quantitative descriptive study with cross sectional data collection had been done during September until October 2015. Subjects were students from 5 high schools registered in Jatinangor, who were seat in 10 and 11 classes. Blood samples were taken and used for routine hematology examination and one tube osmotic fragility test (OTOFT). While menzter index is calculated from $M C V$ divided by RBC number. Beta thalassemia minor is suspected if $M C V<80 \mathrm{fL}, M I<13$ and OTOFT is positive. Results from all invited 10 and 11 class of high schools students in Jatinangor, only 292 came, and 130 willing tojoin the study. This study found that $12(9,3 \%)$ students were suspected beta thalassemia minor. Discussion this study found $9,3 \%$ high schools students in Jatinangor are beta thalassemia minor, other study in Banyumas found it is only $8 \% .{ }^{14}$
\end{abstract}

Keywords: Beta Thalassemia Minor, Screening, Thalassemia.

Korespondensi:

Putri Alyumnah

Fakultas Kedokteran Universitas Padjadjaran

Jalan Raya Bandung-Sumedang KM. 21 Jatinangor, Sumedang, Jawa Barat, Indonesia

Mobile : 085723911090

Email :putrialyumnah@gmail.com 


\section{Pendahuluan}

Thalassemia merupakan kelainan genetik pada susunan asam amino pembentuk satu atau lebih rantai globin pada hemoglobin sel darah merah. ${ }^{2}$ Lahirnyapenyandangbaruthalassemiadiakibatkan dari perkawinan sesama pembawa gen. ${ }^{1,} 2$ WHO menyatakan bahwa di Indonesia terdapat $6-10 \%$ orang dengan thalassemia beta minor. ${ }^{13}$

Angka kejadian thalassemia dapat ditekan dengan melakukan edukasi dan skrining terhadap pembawa gen thalassemia beta. $^{3}$ Kegiatan ini menjadi sangat penting untuk mendeteksi thalassemia beta minor, luaran klinik dari pembawa gen thalassemia beta, karena tidak menimbulkan gejala sehingga sulit untuk dideteksi. ${ }^{7}$ Skrining awal kelainan ini untuk menetapkan tersangka thalassemia, sebelum diagnosis pasti melalui pemeriksaan genetik, sederhana dan mudah dilakukan. Pemeriksaan hematologi sederhana berupa kadar $\mathrm{Hb}$, jumlah sel darah merah, MCV, tes fragilitas osmotik tabung tunggal/One Tube Osmotic Fragility Test (OTOFT) dan Indeks Mentzer telah diketahui dan teruji dapatmenentukan tersangka thalassemia. ${ }^{1,5-7}$

Provinsi Jawa Barat merupakan daerah dengan prevalensi thalassemia terbanyak seIndonesia sebanyak yaitu $42 \%$ dari total 6647 orang. ${ }^{4,9}$ Sampai dengan tahun 2013, Pemerintah Jawa Barat baru saja menyelesaikan penyusunan petunjuk teknis (juknis) dan pilot project di Kota Bandung dan Kab. Garut dalam pengendalian thalassemia, namun belum ada program skrining thalassemia yang rutin dilakukan terhadap individu usia subur siap menikah. ${ }^{8}$ Metode ini sangat efektif jika dilakukan pada populasi untuk menekan kejadian thalassemia baru. ${ }^{19}$ Individu usia subur siap menikah ini mudah dijaring melalui edukasi (penyuluhan) saat usia Sekolah Menengah Atas (SMA) dan akan sangat bermanfaat sebagai "agent of change" untuk memutus rantai thalassemia.

Kecamatan Jatinangor, Jawa Barat adalah salah satu kawasan pendidikan yang terkenal dengan terdapat beberapa perguruan tinggi negeri ternama. Berdasarkan data statistik tahun 2014, di kecamatan ini terdapat 5 SMA dengan total siswa yaitu 2.212 orang.

Maka berdasarkan data diatas, kami melakukan deteksi dini terhadap tersangka thalassemia beta minor dengan melakukan skrining awal menggunakan indikator panel sel darah merah yang sederhana pada siswa SMA di Kecamatan Jatinangor. Kegiatan ini bertujuan untuk mengetahui jumlah tersangka thalassemia beta minor pada siswa-siswi SMA di Jatinangor.

\section{Metode}

Penelitan deskriptif kuantitatif mengaplikasikan teknik pengambilan data potong lintang dilakukan dengan perhitungan besaran sampel untuk memenuhi interval kepercayaan 95\%. Jumlah sampel yang digunakan adalah 130 orang. Subyek penelitian adalah siswa-siswi SMA kelas 10 dan 11 yang memenuhi kriteria inklusi. Kriteria inklusi adalah siswa yang berada di kelas 10 atau 11, belum diketahui menyandang thalassemia minor, dan bersedia mengikuti penelitian, serta mengembalikan lembar informed consent yang telah ditandatangan. Kriteria eksklusi yaitu telah diketahui menyandang thalassemia, telah mengikuti skrining thalassemia dengan menunjukkan bukti skrining, dan sampel darah yang lisis atau tidak dapat digunakan.

Penyuluhan dilakukan untuk menjaring subyek penelitian dan dilanjutkan dengan distribusi informed consent kepada subyek penelitian. Mereka yang menandatangani informed consent atas sepengetahuan orang tua masing-masing menjalani pemeriksaan laboratorium darah.

Pengambilan darah dari subjek penelitian adalah sebanyak $3 \mathrm{~mL}$, dimasukkan ke dalam tabung EDTA, dan dilakukan oleh analis laboratorium terlatih dari Departemen/SMF Patologi Klinik Rumah Sakit Dr. Hasan Sadikin (RSHS) Bandung. Prosedur pengambilan sampel darah dilakukan sesuai standar yang sudah ditetapkan. Sebanyak $5 \mu \mathrm{L}$ darah diambil dari masing-masing tabung EDTA diambil untuk dilakukan pemeriksaan OTOFT di lokasi penelitian. Sampel darah yang telah terkumpul dimasukkan ke dalam cool box dan segera dibawa ke Laboratorium Patologi Klinik RSHS untuk dilakukan pemeriksaan hematologi meliputi pemeriksaan kadar $\mathrm{Hb}$, jumlah eritrosit, dan MCV dengan menggunakan mesin hematology analyzer serta perhitungan Indeks Mentzer.

Indeks Mentzer adalah parameter yang diperoleh dari pembagian nilai MCV dengan jumlah eritrosit. Indeks Mentzer dapat digunakan hanya pada keadaan anemia ringan yaitu jika kadar $\mathrm{Hb}$ 10,0-11,9 g/dL, karena pada penelitian sebelumnya juga didapatkan kadar $\mathrm{Hb}$ pada kelompok subyek dengan beta thalassemia minor yaitu 9-11,46 g/dL dan pada kelompok subyek dengan anemia defisiensi besi kadar $\mathrm{Hb}$ nya 8,7-11,4 g/dL dengan MCV $<80$ fL. ${ }^{2,5}$

Untuk mengidentifikasi tersangka thalassemia beta minor diawali dengan melihat status eritrosit subyek dari data hasil pemeriksaan laboratorium berupa kadar $\mathrm{Hb}$, jumlah eritrosit, dan MCV. Setelah itu dilakukan perhitungan 
indeks Mentzer. Selanjutnya dapat ditentukan subyek sebagai tersangka Thalassemia beta minor dengan memenuhi kriteria yaitu $\mathrm{MCV}<80$ $\mathrm{fL}$, Indeks Mentzer $<13$ dan OTOFT positif., ${ }^{2,5}$ Data hasil pemeriksaan yang dianalisis dengan menggunakan program pengolahan data SPSS.

Subyek penelitian pasca pemeriksaan darah yang diduga menyandang thalassemia beta minor mendapatkan kartu penanda telah dilakukan skrining thalassemia kepada subyek penelitian. Selain itu juga dilakukan konseling kepada subyek yang merupakan tersangka thalassemia beta minor.

Penelitian ini telah mendapat persetujuan dari Komite Etik Penelitian Kesehatan Fakultas
Kedokteran Universitas Padjadjaran/RSUP Dr. Hasan Sadikin Bandung (No:517/UN6.C1.3.2/ KEPK/PN/2015).

\section{Hasil}

Dari total 1.540 siswa SMA kelas 10 dan 11 di 5 sekolah di Jatinangor, sebanyak 292 (18,96\%) orang yang mengikuti penyuluhan thalassemia. Karakteristik populasi penelitian tercantum pada tabel 1. Sebanyak 129 orang mengikuti skrining tersangka thalassemia beta minor. Didapatkan status eritrosit, perhitungan indeks Mentzer dan

Tabel 1 Karakteristik Populasi

\begin{tabular}{lcc}
\hline \multicolumn{1}{c}{ Karakteristik populasi } & n & Median \\
\hline Usia (tahun) & & 16 \\
Jenis kelamin & 97 & \\
- Perempuan (orang) & 32 & \\
- Laki - laki (orang) & 129 & \\
Sampel terinkusi & 1 & \\
Sampel tereksklusi & & \\
\hline
\end{tabular}

hasil OTOFT pada tabel 2. Pada penelitian ini didapatkan bahwa ada 43 orang subyek dengan $\mathrm{MCV}<80 \mathrm{fL}, 14$ orang dengan Indeks Mentzer $<13$ dan 19 orang dengan OTOFT positif (tabel 3.Parameter skrining thalassemia beta minor). Pada penelitian ini ditemukan tersangka thalassemia beta minor pada siswa- siswi SMA di Jatinangor, denganfrekuensiyaitu 12(9,3\%)orang.

\section{Pembahasan}

Dari penelitian yang kami lakukan berupa skrining tersangka thalassemia beta minor pada siswa SMA di Kecamatan Jatinangor, Jawa Barat melalui penyuluhan thalassemia, diketahui terdapat tersangka thalassemia beta minor dengan prevalensi sebesar 9,3\%.

Lahirnya penyandang thalassemia baru yang berasal dari pernikahan pembawa sifat thalassemia beta (thalassemia beta minor) merupakan masalah kesehatan dunia. sehingga menjadikan edukasidanskrining terhadap thalassemia beta minor menjadi isu yang penting. Thalassemia beta minor bersifat asimtomatik sehingga sulit dideteksi, maka perlunya meningkatkan kesadaran melalui edukasi terhadap pentingnya melakukan skrining. ${ }^{5,7}$ Skrining talasemia pada populasi premarital merupakan program pencegahan yang telah dilakukan akan tetapi program seperti itu tidak sepenuhnya telah terimplementasikan di Indonesia, khususnya di Jawa Barat. $^{6}$

Tabel 2 Status Eritrosit

\begin{tabular}{lccc}
\hline \multicolumn{1}{c}{ Parameter } & Mean $( \pm$ SD) & Median & n \\
\hline Hemoglobin $(\mathrm{g} / \mathrm{dL})$ & $13,3( \pm 1,5)$ & & \\
MCV $(\mathrm{fL})$ & & 81,60 & \\
$\mathrm{RBC}(\times 106 / \mu \mathrm{L})$ & 4.850 & \\
Indeks Mentzer & & 16,701 & \\
OTOFT $(\mathrm{n})$ & & 19 \\
• Positif & & 110 \\
• Negatif & & & \\
\hline
\end{tabular}


Tabel 3 Parameter Skrining Thalassemia Beta Minor

\begin{tabular}{lcc}
\hline \multicolumn{1}{c}{ Karakteristik } & $\mathbf{n}$ & $\mathbf{\%}$ \\
\hline $\mathrm{MCV}<80 \mathrm{fL}$ & & \\
Positif $(\mathrm{MCV}<80 \mathrm{fL})$ & 43 & $33,3 \%$ \\
Indeks Mentzer $<13$ & & \\
Positif $(<13)$ & 14 & $10,9 \%$ \\
Tes Fragilitas Osmotik Tabung Tunggal & & \\
Positif & 19 & $14,7 \%$ \\
\hline
\end{tabular}

Penelitian ini merupakan bagian dari langkah awal dalam meningkatkan program promotif dan preventif terhadap penekanan angka thalassemia baru melalui identifikasi thalassemia beta minor di wilayah kerja puskesmas Jatinangor, dengan cara mengedukasi siswa-siswi SMA melalui penyuluhandandilakukannyaskriningthalassemia di sekolah-sekolah. Sekolah sebagai fasilitas penyuluhan merupakan tempat yang efektif karena sekolah merupakan tempat dilaksanakannya proses pembelajaran.Hasil menunjukkan bahwa terdapat tersangka thalassemia beta minor di siswa-siswi SMA di Jatinangor, hasil dari penelitian ini menunjang data thalassemia bata minor di Jawa Barat yang tergolong tinggi. ${ }^{8,9}$

Berdasarkan karakteristik populasi, dari 292 peserta yang hadir saat penyuluhan hanya ada $129(44,17 \%)$ orang yang melakukan skrining thalassemia. Pada penelitian ini tidak dilakukan pengukuran tingkat pengetahuan sebelum dan setelah dilakukan penyuluhan. Fenomena ini menunjukan adanya peranan pengetahuan mengenai thalassemia mempengaruhi kesadaran subyek untuk melakukan skrining. Menurut studi sebelumnya tingkat pengetahuan sesungguhnya sangat berpengaruh terhadap tingkat kesehatan seseorang. ${ }^{10}$ Oleh sebab itu perlu dilakukan penelitian selanjutnya mengenai tingkat pengetahuan terhadap thalassemia beta minor sebelum dilakukan skrining. Thalassemia merupakan kelainan genetik tidak terkait kromosom seks. ${ }^{11,12}$ Dari 129 subyek yang melakukan skrining di antaranya lebih banyak perempuan dibanding laki-laki, karena jumlah murid perempuan di sekolah lebih banyak dibandingkan murid laki-laki.

Pada thalassemia beta minor tidak terdapat tanda-tanda anemis yang signifikan. Bila dilihat secara umum dari status eritrosit subyek, kadar $\mathrm{Hb}$ pada tersangka thalassemia beta minor tidak menunjukan kadar $\mathrm{Hb}$ yang rendah atau tidak menunjukan anemis. ${ }^{20}$ Tersangka thalassemia

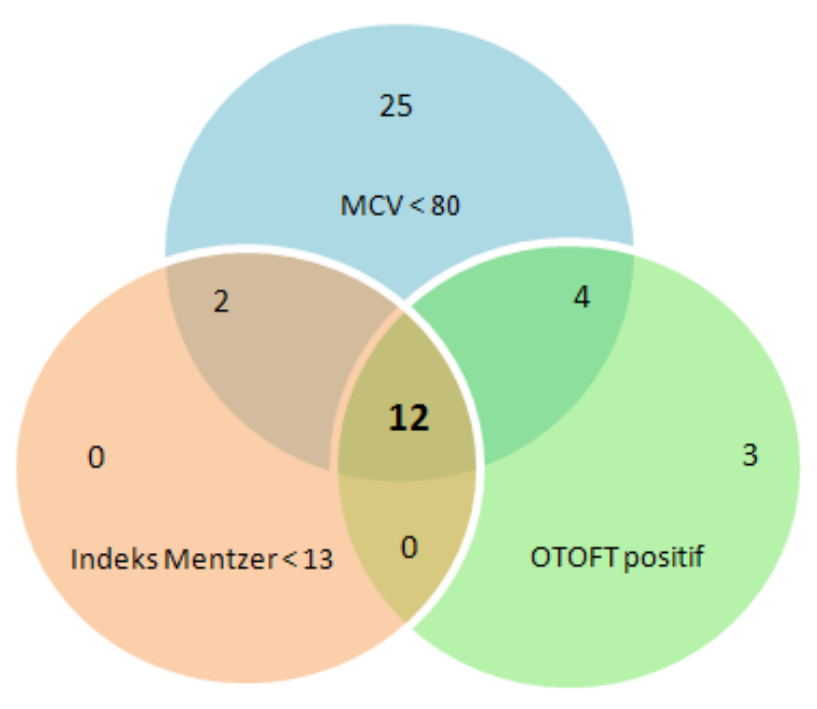

Gambar 1 Irisan parameter hematologi 
beta minor terlihat seperti hal nya orang normal pada umumnya sebab mereka tidak merasa sakit dan tidak bergejala (asimtomatik). ${ }^{7,18} \mathrm{Hal}$ inilah yang menyebabkan thalassemia beta minor sulit untuk dideteksi dan oleh sebab itu peranan skrining thalassemia menjadi sangat penting.

Untuk melakukan deteksi dini terhadap thalassemia beta minor tidaklah sulit karena pada penelitian ini parameter yang digunakan adalah kadar hemoglobin, jumlah sel darah merah, $\mathrm{MCV}, \mathrm{MCH}$, Tes Fragilitas Osmotik Tabung Tunggal, dan Indeks Mentzer, seperti yang telah dilakukan peneliti sebelumnya.2 Menurut hasil penelitian sebelumnya menunjukkan bahwa dengan cut off point $\mathrm{MCV}<80 \mathrm{fL}$ memiliki nilai senisitivitas $81,3 \%$ dan spesifisitas $95,8 \% .^{14}$

Kecurigaan terhadap thalassemia beta minor dapat diidentifikasi dengan melihat hasil pemeriksaan darah yang menunjukan nilai rujukan $\mathrm{MCV}<80 \mathrm{fL}$, Indeks Mentzer <13 dan OTOFT positif.5 Tes fragilitas osmotik (OTOFT) perlu dilakukan untuk memastikan adanya perubahan pada membran eritrosit. Bila ditemukan nilai $\mathrm{MCV}<80 \mathrm{fL}$, diperlukan perhitungan Indeks Mentzer untuk membedakan thalassemia beta minor dari defisiensi besi.

Kemudian dari hasil skrining secara keseluruhan selain ada 83 orang yang normal juga pada penelitian ini ditemukan beberapa keadaan yang mengganggu pemeriksaan seperti hal nya defisiensi besi, mereka yang hasil pemeriksaannya tidak memenuhi ketiga kriteria tersebut dan dicurigai mengalami defisisensi besi maka harus diterapi besi terlebih dulu untuk selanjutnya dapat dilakukan skrining thalassemia ulang,karena defisiensi besi dapat mengganggu hasil pemeriksaan. ${ }^{15,16}$

Berdasarkan penelitian sebelumnya diketahui bahwa Thailand, semenanjung Malaysia, kepulauan Pasifik dan Indonesia menduduki angka insidensi thalassemia tertinggi di wilayah Asia dan Asia bagaian selatan. ${ }^{12}$ Menurut laporan Yayasan Thalassemia Indonesia-Perhimpunan Orang tua Penderita Thalassemia (YTI-POPTI) Pusat, tercatat ada 5.501 penderita thalassemia di Indonesia dan sekitar 35\% atau 1.751 orang di antaranya berasal dari Jawa Barat. ${ }^{13}$ Sesuai dengan distribusi geografis untuk thalassemia beta yang terkonsentrasi pada lintasan "thalassemia belt" yang terbentang dari bagian timur mediterania, melewatiTimur Tengah dan India lalu ke bagian selatan Asia sampai ke bagian selatan dan utara Afrika dan indonesia termasuk di dalamnya, jadi tak heran jika angka di Indonesia cukup tinggi terutama di Jawa Barat. ${ }^{17}$

Keterbatasan dalam penelitian ini tidak dilakukannya diagnosis pasti yaitu dengan pemeriksaan genetik, karena penelitian ini merupakan skrining tersangka thalassemia beta minor. Kesimpulan dari penelitian ini bahwa thalassemia beta minor bersifat asimtomatik sehingga tidak akan pernah mengetahui bahwa dirinya sebagai tersangka sebelum memeriksakan diri. Hal ini membuat peran deteksi dini terhadap thalassemia beta minor berperan penting dalam memutus kelahiran penyandang thalassemia baru. Kesadaran masyarakat untuk memeriksakan diri tidak lepas kesadaran mereka melalui edukasi atau penyuluhan.

Saran untuk penelitian selanjutnyaya itu penelitian ini perlu dilanjutkan dengan pemeriksaan elektroforesis $\mathrm{Hb}$ dan analisis DNA sebagai gold standard untuk mendiagnosis pasti thalassemia betaminor. ${ }^{16}$ Selainituperlu dilakukan konseling pada subjek tersangka thalassemia beta minor dan dianjurkan melanjutkan pemeriksaan pada orang tua dan saudara kandung dari subyek penelitian sehingga dapat terbentuk pedigree yang dapat digunakan pada basis data penyebaran thalassemia pada dinas kependudukan, khususnya di Provinsi Jawa Barat.

\section{Daftar Pustaka}

1. Gallanello R, Origa R. Beta-thalassemia. Orphanet Jounal of Rare Disease. 2010;5(11):1-15.

2. Yousafzai YM, Khan S, Raziq F. $\beta$-Thalassemia Trait: Haematological Parameters.J Ayub Med Coll Abbottabad. 2010;22(4):84-6.

3. Mulyani, Adi Fahrudin. Reaksi Psikososial Terhadap Penyakit Dikalangan Anak Penderita Thalassemia Mayor di Kota Bandung.Informasi. 2011;16(3):157-76.

4. Online PR. Tahun 2014, Jumlah Penderita Talasemia Tercatat 6.647 Orang. Bandung: Pikiran Rakyat, Bandung; 2016 [updated 29 Mei, 2015 - 04:29; cited 2016 Tuesday, 1st March 2016]; Available from:http://www.pikiran-rakyat.com/ horison/2015/05/29/329047/tahun-2014jumlah-penderita-talasemia-tercatat-6647orang.

5. Kementerian Kesehatan RI. Health Technology Assessment Indonesia. Pencegahan Thalassemia2010. p. 6.

6. Eva A Maharani, Yuyun S M, Soedarmono,Ita M Nainggolan. Frequency of thalassemia carrier and $\mathrm{Hb}$ variant and the quality of stored donor blood. Medical Journal Indonesia. 2014;23(4):209-12.

7. Qazi RA. Screening for Beta Thalassemia Trait. Journal of Rawalpindi Medical College. 2014;18(1):158-60. 
8. Kementerian Kesehatan RI. Profil Kesehatan Indonesia Tahun 2013. Jakarta: Kementerian Kesehatan Republik Indonesia; 2014; Available from: http://www.depkes.go.id/ resources/download/pusdatin/profilkesehatan-indonesia/profil-kesehatanindonesia-2013.pdf.

9. RI BPDPKDK. Laporan Hasil Riset Kesehatan Dasar (RISKESDAS) Provinsi Jawabarat Tahun 2007. Jakarta Departemen Kesehatan RI, 2009.

10. Brunello G, Fort M, Schneeweis N, WinterEbmer R. The Causal Effect of Education on Health: What is the Role of Health Behaviors. The Institute for the Study of Labor. 2011:237.

11. Grow K, Vashist M, Abrol P, Sharma S, Yadav R. Beta Thalassemia In India:Current Status And The Challenges Ahead. International Journal of Pharmacy and Pharmaceutical Sciences. 2014;6(4):28-33.

12. Langlois S, Ford JC, Chitayat D. Carrier Screening for Thalassemia and Hemoglobinopathies in Canada. Joint SOGC-CCMG Clinical Prectice Guideline 2008; 218: 950-959.

13. Rumah Sakit Hasan Sadikin. 6-10\% Masyarakat Indonesia Memiliki Keturunan Thalassemia. Bandung: Rumah Sakit Hasan Sadikin; 2011. Available from: http://web. rshs.or.id/who-6-10-masyarakat-indonesiamemiliki-keturunan-thalassemia/
14. Ariadne Tiara Hapsari, Lantip Rujito. Uji Diagnostik Indeks Darah dan Identifikasi Molekuler Karier Talasemia beta pada Pendonor Darah di Banyumas. Jurnal Kedokteran Brawijaya. 2015;28(3):233-7.

15. Tabatabaei.S R, Ashtiani R, Tavakkolifard A, Jahromy MH, Shiva F, Ghazi-Saieedi M, et al. The prevalence of minor thalassemia among siblings of major thalassemia patients. Annals of Biological Research. 2012;3(12):5429-33.

16. Vehapoglu A, Ozgurhan G, Demir AD, Uzuner S, Nursoy MA, Turkmen S, et al. Hematological Indices for Differential Diagnosis of Beta Thalassemia Trait and Iron Deficiency Anemia. Hindawi. 2014:1-7.

17. Hashemizadeh.H, Noori.R. Premarital Screening of Beta Thalassemia Minor in north-east of Iran. Iranian Journal of Pediatric Hematology Oncology. 2012;3(1):29-34.

18. Rund D, Rachmilewitz E. Beta Thalassemia. The new england journal of medicine. 2005;353(11):1135-46.

19. Datar S, Poflee S, Shrikhande A. Premarital screening of college students for carrier detection in thalassemia and sickle cell disease. International Journal of Medical Science and Public Health. 2015;3(15):4203.

20. Rachmilewitz EA, Giardina PJ. How I treat thalassemia. Blood Journal. 2011;118(13): 3479-88. 